\title{
Comparison of Molly and Karoline models to predict methane production in growing and dairy cattle
}

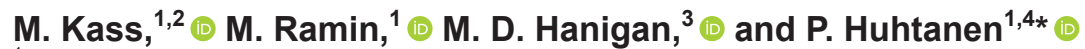 \\ ${ }^{1}$ Department of Agricultural Research for Northern Sweden, Swedish University of Agricultural Sciences, 90183 Skogsmarksgränd, Umeå, \\ Sweden \\ ${ }^{2}$ Chair of Animal Nutrition, Institute of Veterinary Medicine and Animal Sciences, Estonian University of Life Sciences, Fr. R. Kreutzwaldi Str. 46, \\ 51006 Tartu, Estonia \\ ${ }^{3}$ Department of Dairy Science, Virginia Tech, 3310 Litton Reaves, Blacksburg 24061 \\ ${ }^{4}$ Production Systems, Natural Resources Institute Finland (LUKE), 31600 Jokioinen, Finland
}

\section{ABSTRACT}

Numerous empirical and mechanistic models predicting methane $\left(\mathrm{CH}_{4}\right)$ production are available. The aim of this work was to evaluate the Molly cow model and the Nordic cow model Karoline in predicting $\mathrm{CH}_{4}$ production in cattle using a data set consisting of 267 treatment means from 55 respiration chamber studies. The dietary and animal characteristics used for the model evaluation represent the range of diets fed to dairy and growing cattle. Feedlot diets and diets containing additives mitigating $\mathrm{CH}_{4}$ production were not included in the data set. The relationships between observed and predicted $\mathrm{CH}_{4}\left(\mathrm{pCH}_{4}\right)$ were assessed by regression analysis using fixed and mixed model analysis. Residual analysis was conducted to evaluate which dietary factors were related to prediction errors. The fixed model analysis showed that the Molly predictions were related to the observed data ( \pm standard error) as $\mathrm{CH}_{4}(\mathrm{~g} / \mathrm{d})=0.94( \pm 0.022) \times \mathrm{pCH}_{4}(\mathrm{~g} / \mathrm{d})+31( \pm 6.9)$ [root mean squared prediction error $(\mathrm{RMSPE})=45.0$ $\mathrm{g} / \mathrm{d}(14.9 \%$ of observed mean), concordance correlation coefficient $(\mathrm{CCC})=0.925]$. The corresponding equation for the Karoline model was $\mathrm{CH}_{4}(\mathrm{~g} / \mathrm{d})=\mathrm{CH}_{4}(\mathrm{~g} / \mathrm{d})=$ $0.98( \pm 0.019) \times \mathrm{pCH}_{4}(\mathrm{~g} / \mathrm{d})+7.0( \pm 6.0)[\mathrm{RMSPE}=$ $35.0 \mathrm{~g} / \mathrm{d}(11.6 \%), \mathrm{CCC}=0.953]$. Proportions of mean squared prediction error attributable to mean and linear bias and random error were 10.6, 2.2, and $87.2 \%$ for the Molly model, and 1.3, 0.3, and $98.6 \%$ for the Karoline model, respectively. Mean and linear bias were significant for the Molly model but not for the Karoline model. With the mixed model regression analysis RMSPE adjusted for random study effects were 10.9 and $7.9 \%$ for the Molly model and the Karoline model, re-

Received May 31, 2021.

Accepted November 25, 2021.

*Corresponding author: pekka.huhtanen@slu.se or pekka. huhtanen@luke.fi spectively. The residuals of $\mathrm{CH}_{4}$ predictions were more strongly related to factors associated with $\mathrm{CH}_{4}$ production (feeding level, digestibility, fat concentrations) with the Molly model compared with the Karoline model. Especially large mean (underprediction) and linear bias (overprediction of low digestibility diets relative to high digestibility diets) contributed to the prediction error of $\mathrm{CH}_{4}$ yield with the Molly model. It was concluded that both models could be used for prediction of $\mathrm{CH}_{4}$ production in cattle, but Karoline was more accurate and precise based on smaller RMSPE, mean bias, and slope bias, and greater CCC. The importance of accurate input data of key variables affecting diet digestibility is emphasized.

Key words: dynamic model, methane production, prediction equation, cattle

\section{INTRODUCTION}

Methane $\left(\mathrm{CH}_{4}\right)$ is a greenhouse gas contributing to global climate change. Methane production in ruminants is also associated with energy losses, the amount depending on the type of diet and intake level (Johnson and Johnson, 1995). As the direct measurement of $\mathrm{CH}_{4}$ (e.g., in respiration chamber) is relatively expensive and labor intensive, numerous empirical equations (Blaxter and Clapperton, 1965; Moe and Tyrrell, 1979) and mechanistic models (Benchaar et al., 1998; Mills et al., 2001; Kebreab et al., 2008) to predict $\mathrm{CH}_{4}$ production are reported in the literature. However, sometimes the models predicting $\mathrm{CH}_{4}$ production are evaluated using rather small data sets (Axelsson, 1949; Blaxter and Clapperton, 1965), or data from a single laboratory (Yan et al., 2000; Jentsch et al., 2007) and in some cases the data do not cover a wide range of intake and diet composition (Moate et al., 2011).

The respiration chamber method, a gold standard to measure $\mathrm{CH}_{4}$ output, demands significant investment, limiting its widespread use for studying the effect of the full range of diets. Moreover, the IPCC 
(2006) models may not be applicable under different dietary conditions. Models predicting $\mathrm{CH}_{4}$ production can be used to estimate national inventories of $\mathrm{CH}_{4}$ emissions. Therefore, to improve the development of mechanistic prediction models and their performance, collaborations between researchers across the world is encouraged (Hristov et al., 2018). We chose 2 models originally compiled to predict nutrient absorption from the digestive tract and metabolized in various tissues, to test their performance in predicting $\mathrm{CH}_{4}$ production by cattle.

The Molly cow model is a mechanistic, dynamic model describing digestion and metabolism of cattle with the ability to predict animal-related factors that affect the environment, including $\mathrm{CH}_{4}$ production (Baldwin et al., 1987; Hanigan et al., 2013). The Nordic cow model Karoline is a dynamic, mechanistic model describing digestion and metabolism in dairy cows (Danfær et al., 2006), and its revised form (Huhtanen et al., 2015) was confirmed by Ramin and Huhtanen (2015) to be a useful tool in predicting $\mathrm{CH}_{4}$ production in cattle.

However, there is not any direct comparison of these models using a large common data set. This is problematic as indirect comparisons can be biased due to differences in the scope of the observed data. Therefore, the objective of the current study was to evaluate the Molly and Karoline mechanistic models for predicting $\mathrm{CH}_{4}$ production using a common data set of respiration chamber studies.

\section{MATERIALS AND METHODS}

\section{Development of Data Set}

The data set used consisted of observations of $\mathrm{CH}_{4}$ production from 267 treatments reported in 55 respiration chambers studies. A subset of 31 papers published between 1964 and 2013 with a total of 184 observations (each one a treatment mean) has been described in more detail by Ramin and Huhtanen (2015). The additional data added were identified from a survey of literature performed using the Web of Science database in early 2016. This resulted in identification of an additional 24 publications containing 90 treatments published between 2013 and 2015. Of these 24 papers, 16 studies were conducted with lactating dairy cattle and 8 with growing cattle (dairy and beef breeds). The references of studies used are presented in Supplemental Data File S1 (https://doi.org/10.17632/83cg3jbmsh.1; Kass, 2022).

Inclusion of studies in the data set was subject to the following criteria: (1) $\mathrm{CH}_{4}$ production were measured using a respiration chamber, (2) treatments did not include feed additives (e.g., monensin, tannins, 3-nitroxypropanol, and so on), (3) dietary ingredient composition and forage analysis of fiber (e.g., in vitro OM digestibility, NDF, ADF) were reported, and (4) total DMI and BW were reported. Chemical composition of diets was collected from the published papers, and when compositional data were not reported, tabulated values from the National Research Council (NRC, 2001) and the Cornell Net Carbohydrate and Protein System (CNCPS; Tylutki et al., 2008) were used. Data on rumen fermentation characteristics, and diet digestibility were added to the data set when reported. Milk yield, when reported $(\mathrm{n}=36)$, was $28.0 \pm 7.1 \mathrm{~kg} / \mathrm{d}$. Average daily weight gain, when reported $(\mathrm{n}=5)$, was $0.83 \pm 0.13 \mathrm{~kg} / \mathrm{d}$.

For other parameters, such as protein fractions, indigestible NDF, digestion rates of potentially digestible NDF, starch and insoluble CP, and so on, tabulated values were used or estimated from equations published in the literature. For the Karoline model, Huhtanen et al. (2015) described details of the derivation of digestion kinetic parameters. The objective was to compile a data set to cover a wide range of dietary composition from experiments that had studied the effects of feeding level, proportion of concentrate supplementation, protein and fat supplementation, carbohydrate composition of concentrate supplements, forage type, maturity of forage crops at harvest, and silage fermentation quality. Studies with diets including more than $70 \%$ concentrate on a DM basis were excluded from the final data set because they are not considered typical dairy cattle diets.

Methane production was expressed as grams per day, liters per day, megajoules per day, or as a proportion of gross energy or digestible energy. The following factors were used in converting among $\mathrm{CH}_{4}$ units: $1 \mathrm{~g}=1.40$ $\mathrm{L}=55.5 \mathrm{~kJ}$. The values are based on a molar mass of $16.04 \mathrm{~g}$ and gas volume of $22.4 \mathrm{~L} / \mathrm{mol}$.

\section{Molly Simulations}

The Molly cow model simulations were conducted using the model of Baldwin (Baldwin, 1995) with updates described by Hanigan and coworkers (Boston and Hanigan, 2000; Hanigan et al., 2007, 2008, 2009, 2013; Gregorini et al., 2015) and ACSLX (Ver. 3.0.2.1 Aegis Technologies Group). Integration was conducted using a variable step Runge-Kutta algorithm with a maximum step size of $0.1 \mathrm{~d}$. Inputs included BW, BCS, DMI, and dietary nutrient composition. Dry matter intake, BW, and BCS [reported in 4 studies, 2 with lactating cattle $(2.96 \pm 0.27)$ and 2 studies with growing cattle $(2.74 \pm$ $0.27)$ were as reported in the publications. All studies reported DMI. If BCS was not reported, a value of 3.0 was used. Body condition score, although required 
by the model, has no bearing on gut metabolism. The nutrient composition of each diet was constructed as follows: (1) dietary ingredients were merged with the 2001 NRC feed library and reported nutrient data; (2) reported ingredient data were used to adjust the library values where available; (3) the predicted dietary nutrient composition was compared with the reported values for each diet and deviations from reported dietary values (where available) were calculated; (4) a mean deviation in dietary values was determined for each study and used to adjust the nutrient concentrations of each ingredient used in the study proportional to its contribution to the study to remove mean bias in nutrient inputs. The model was configured to simulate each diet, and model predicted values were collected after the model reached steady state (at the end of a 10-d simulation) for comparison to observed values.

\section{Karoline Simulations}

The Karoline model (Danfær et al., 2006) consists of 2 submodels: a digestion and a metabolism model. The first describes digestion in the fore-stomachs, the small intestine and the hindgut, whereas the second consists of portal-drained viscera, liver, extracellular fluid, and mammary glands, as well as muscle, and connective and adipose tissues. The current simulations used only the digestion submodel, in which urea recycling into the digestive tract was based on empirical equations. The model inputs are BW, DMI, and DM composition. Parameters describing the feeds are CP, crude fat, potentially degradable NDF (pdNDF), indigestible NDF (iNDF), starch, fermentation products (lactate, acetate, propionate, and butyrate) and the residual fraction (includes sugars, pectin, and other OM that are not accounted for by other feed fractions). The $\mathrm{CP}$ fraction is further divided into ammonia $\mathrm{N}, \mathrm{AA}$, peptide, soluble protein, insoluble protein, and indigestible protein N. Digestion rate constants for ruminal digestion of pdNDF, insoluble protein, and starch must be provided for each feed ingredient. In the digestion submodel, ruminal digestion and passage of carbohydrates and protein are described using 2-compartment models considering selective retention of feed particles in the rumen (Allen and Mertens, 1988). Rates of passage from the rumen are regulated by the NDF intake per kilogram of BW. Forage and concentrate pdNDF and iNDF are modeled as different compartments as the passage kinetic parameters are different for forages and concentrates. Aggregated fractional rate of digestion $\left(k_{d}\right)$ values were calculated separately for forage pdNDF, concentrate pdNDF, forage insoluble protein, and concentrate insoluble protein from digestion rates of dietary ingredients as described by Danfær et al.
(2006). The rate of NDF degradation in the rumen is regulated by the ratio of NFC to NDF (Huhtanen et al., 2015). The fermentation pattern in the rumen is predicted by stoichiometric equations (Sveinbjörnsson et al., 2006) adjusted for feeding level (DMI/BW) and dietary concentration of concentrate crude fat. The efficiency of microbial protein synthesis depends on the ruminal level of ammonia $\mathrm{N}$ (downregulated at low concentrations) and free AA + peptide concentrations (upregulated at high concentrations). Recently the submodel predicting $\mathrm{CH}_{4}$ production was revised and described in more detail by Huhtanen et al. (2015). Simulations were made by Microsoft Office Excel (Microsoft Corp.) software using simulation time of 480 $\mathrm{h}$ to reach steady state with a time step of $0.1 \mathrm{~h}$. In validation, the Excel version of the model resulted in the same output as the original Powersim version using the Runge-Kutta 4 algorithm (Huhtanen, 2015).

\section{Statistical Analysis}

The relationships between predicted and observed digestibility and $\mathrm{CH}_{4}$ production were assessed by using the linear regression technique (FIXED model). The performance of both models within a study was further evaluated by using the MIXED regression model procedure of SAS (Littell et al., 1996) with a random study effect. The relationship between independent and dependent variables was estimated by using the following model:

$$
Y_{i j}=B_{0}+B_{1} X_{1 i j}+b_{0}+b_{1} X_{1 i j}+e_{i j}
$$

where $Y_{i j}$ is the observed value, $B_{0}$ and $B_{1}$ are the fixed effects (intercept and effects of independent $\mathrm{X}_{\mathrm{ij}}$ variables), and $b_{0}$ (intercept), $b_{1}$ (slope), and $e_{i j}$ are the random study effects $(i=1 \ldots 55$ studies and $\mathrm{j}=$ $1 \ldots n_{i}$ values). Root mean square error of prediction (RMSPE) was calculated as

$$
\text { RMSPE }=\sqrt{ }\left[\Sigma(\text { observed }- \text { predicted })^{2} / \mathrm{n}\right] .
$$

Mean squared error was decomposed into random error, error due to the deviation of regression slope from unity (linear bias), and error due to overall bias as described by Bibby and Toutenburg (1977). The concordance correlation coefficient (CCC; Lin, 1989) was calculated to assess the precision and accuracy of predicted versus observed values of $\mathrm{CH}_{4}$ production. Residual analysis was conducted as described by St-Pierre (2003) for $\mathrm{CH}_{4}$ production by regressing the centered predicted values against the residuals (observed - predicted). To center the predicted values, the mean of all predicted values was subtracted from each predicted value. This makes 
the slope and intercept estimates orthogonal and thereby they can be assessed independently. Assessment of sources of bias was conducted by regression analysis between the residuals (observed - predicted) of $\mathrm{CH}_{4}$ production and variables known to affect $\mathrm{CH}_{4}$ production as total DMI, OM digestibility (OMD), and diet composition. The bias related to rumen VFA pattern was conducted by regression of the residuals of $\mathrm{CH}_{4}$ production on stoichiometric $\mathrm{CH}_{4}$ production (mmol) per mol of VFA calculated according to Wolin (1960).

\section{RESULTS}

\section{Data Description}

Dietary and animal characteristics collected and used in the current study covered the ranges of typical cattle diets (Table 1) and displayed large variation in intake, diet composition, and digestibility. For example, the proportion of concentrate varied from 0 to $70 \%$ on a DM basis. Also, large variations in BW and DMI values were present, driven in part by animal type. The mean BW values for dairy cows were $589 \pm 78.6 \mathrm{~kg}(\mathrm{n}=181)$ and for growing cattle $398 \pm 129.4 \mathrm{~kg}(\mathrm{n}=86)$, and the means for DMI were $17.1 \pm 4.21$ and $7.2 \pm 1.86 \mathrm{~kg} / \mathrm{d}$, respectively.

Table 2 shows predicted values for variables associated with $\mathrm{CH}_{4}$ production. Predicted VFA production was greater $(P<0.001)$ for the Karoline model compared with the Molly model. The Molly model predicted lower $(P<0.001)$ molar proportions of acetate and butyrate, and a higher proportion of propionate $(P$
$<0.001)$ than the Karoline model. As a result of these differences in rumen fermentation patterns, predicted $\mathrm{CH}_{4}$ production per mol of VFA was $21 \%$ higher for the Karoline compared with the Molly model (Table 2). In the Molly model absorption rates of VFA are variable and the predicted ruminal molar proportions of VFA (652, 228, and $120 \mathrm{mmol} / \mathrm{mol}$ for acetate, propionate, and butyrate, respectively) were more similar to the Karoline model than the molar proportions in VFA production. Duodenal flow and fecal output of dietary components were greater $(P<0.001)$ for the Molly than for the Karoline model. Observed fecal OM output was $3.49 \mathrm{~kg} / \mathrm{d}(\mathrm{n}=246)$, whereas predicted values were 3.88 and $3.46 \mathrm{~kg} / \mathrm{d}$ for the Molly and Karoline for these observations. Metabolic fecal output calculated as fecal OM - fecal NDF per kilogram of DMI was much more variable in the Molly predictions compared with the Karoline predictions (Table 2).

\section{Predictions of $\mathrm{CH}_{4}$ Production and Digestibility by the Karoline and Molly Models}

The relationship between observed and predicted $\mathrm{CH}_{4}\left(\mathbf{p} \mathbf{C H}_{4}\right)$ production are presented for Molly and Karoline models using the fixed and mixed model regressions (Figure 1 and Figure 2). The fixed model regression for Molly predictions was

$$
\begin{gathered}
\mathrm{CH}_{4}(\mathrm{~g} / \mathrm{d})=0.94(\mathrm{SE} \pm 0.022) \times \mathrm{pCH}_{4}(\mathrm{~g} / \mathrm{d}) \\
+31( \pm 6.9) \text { with } \mathrm{RMSPE}=45.0 \mathrm{~g} / \mathrm{d} \\
(14.9 \% \text { of observed mean }) .
\end{gathered}
$$

\begin{tabular}{|c|c|c|c|c|c|}
\hline Item & $\mathrm{N}$ & Mean & $\mathrm{SD}$ & Minimum & Maximum \\
\hline DMI, kg/d & 267 & 14.0 & 5.87 & 3.42 & 27.20 \\
\hline Forage DMI, $\mathrm{kg} / \mathrm{d}$ & 267 & 8.6 & 3.57 & 1.36 & 16.31 \\
\hline Concentrate DMI, $\mathrm{kg} / \mathrm{d}$ & 267 & 5.3 & 3.54 & 0.00 & 14.28 \\
\hline Concentrate proportion & 267 & 0.35 & 0.181 & 0.00 & 0.70 \\
\hline $\mathrm{BW}, \mathrm{kg}$ & 267 & 536 & 126.6 & 175 & 740 \\
\hline \multicolumn{6}{|l|}{ Digestibility } \\
\hline $\mathrm{OM}$ & 246 & 0.73 & 0.056 & 0.55 & 0.84 \\
\hline $\mathrm{CP}$ & 153 & 0.67 & 0.069 & 0.26 & 0.84 \\
\hline NDF & 129 & 0.58 & 0.138 & 0.26 & 0.87 \\
\hline \multicolumn{6}{|c|}{ Diet composition, $\mathrm{g} / \mathrm{kg}$ of DM } \\
\hline $\mathrm{OM}$ & 267 & 931 & 18.5 & 865 & 968 \\
\hline $\mathrm{CP}$ & 267 & 168 & 41.0 & 51 & 275 \\
\hline Ether extract & 267 & 38 & 17.0 & 6 & 125 \\
\hline $\mathrm{NDF}$ & 267 & 387 & 87.2 & 153 & 771 \\
\hline $\mathrm{NFC}^{1}$ & 267 & 338 & 88.0 & 81 & 578 \\
\hline \multicolumn{6}{|l|}{ Methane production, $\mathrm{g} / \mathrm{d}$} \\
\hline Observed & 267 & 301 & 116.6 & 89 & 528 \\
\hline Predicted, Molly & 267 & 287 & 115.3 & 61 & 494 \\
\hline Predicted, Karoline & 267 & 300 & 113.1 & 86 & 556 \\
\hline
\end{tabular}

Table 1. Statistical description of the diets and other parameters in the observed data set

${ }^{1}$ Calculated according to NRC (2001): NFC $=\mathrm{OM}-\mathrm{CP}-$ ether extract $-\mathrm{NDF}$. 
Table 2. Model-predicted variables related to $\mathrm{CH}_{4}$ production (267 observations)

\begin{tabular}{|c|c|c|c|c|c|c|}
\hline \multirow[b]{2}{*}{ Item } & \multicolumn{2}{|c|}{ Molly } & \multicolumn{2}{|c|}{ Karoline } & \multirow[b]{2}{*}{ SEM } & \multirow[b]{2}{*}{$P$-value } \\
\hline & Mean & $\mathrm{SD}$ & Mean & SD & & \\
\hline VFA production, mol/d & 81.4 & 36.12 & 85.4 & 35.50 & 0.40 & $<0.001$ \\
\hline \multicolumn{7}{|l|}{ Molar proportion, $\mathrm{mmol} / \mathrm{mol}$} \\
\hline Acetate & 593 & 37.4 & 674 & 20.1 & 1.2 & $<0.001$ \\
\hline Propionate & 274 & 37.4 & 191 & 17.0 & 0.88 & $<0.001$ \\
\hline Butyrate & 133 & 9.3 & 135 & 5.7 & 0.88 & $<0.001$ \\
\hline $\mathrm{CH}_{4} / \mathrm{VFA},{ }^{1} \mathrm{mmol} / \mathrm{mol}$ & 295 & 21.4 & 357 & 12.8 & 0.66 & $<0.001$ \\
\hline \multicolumn{7}{|l|}{ Duodenal flow, $\mathrm{kg} / \mathrm{d}$} \\
\hline $\mathrm{OM}$ & 7.04 & 3.035 & 5.77 & 2.625 & 0.035 & $<0.001$ \\
\hline NDF & 3.02 & 1.432 & 2.47 & 1.168 & 0.033 & $<0.001$ \\
\hline Starch & 1.42 & 0.751 & 0.44 & 0.304 & 0.025 & $<0.001$ \\
\hline Fat & 0.55 & 0.346 & 0.39 & 0.292 & 0.004 & $<0.001$ \\
\hline Microbial N, g/d & 199 & 87.9 & 192 & 88.9 & 1.4 & $<0.001$ \\
\hline Feed N, g/d & 139 & 72.7 & 109 & 64.1 & 1.2 & $<0.001$ \\
\hline \multicolumn{7}{|l|}{ Fecal output } \\
\hline $\mathrm{OM}, \mathrm{kg} / \mathrm{d}$ & 4.06 & 1.733 & 3.53 & 1.585 & 0.029 & $<0.001$ \\
\hline $\mathrm{NDF}, \mathrm{kg} / \mathrm{d}$ & 2.76 & 1.302 & 2.24 & 1.083 & 0.032 & $<0.001$ \\
\hline Nitrogen, g/d & 127 & 47.9 & 99 & 44.3 & 0.62 & $<0.001$ \\
\hline $\mathrm{MFOM}^{2}, \mathrm{~g} / \mathrm{kg}$ of DMI & 95.8 & 19.13 & 90.1 & 6.93 & 0.90 & $<0.001$ \\
\hline
\end{tabular}

${ }^{1}$ Calculated according to Wolin (1960) as follows: $0.5 \times$ acetate $-0.25 \times$ propionate $+0.5 \times$ butyrate. Calculated from proportions in VFA production for the Molly model, and from ruminal VFA proportions for the Karoline model.

${ }^{2} \mathrm{MFOM}=$ metabolic fecal OM (fecal output of OM - NDF per kg of DMI).

The corresponding equation for the Karoline model was

$$
\begin{gathered}
\mathrm{CH}_{4}(\mathrm{~g} / \mathrm{d})=0.98( \pm 0.019) \times \mathrm{pCH}_{4}(\mathrm{~g} / \mathrm{d}) \\
+7.0( \pm 6.0) \text { with } \mathrm{RMSPE}=35.0 \mathrm{~g} / \mathrm{d} \\
(11.6 \% \text { of observed mean }) .
\end{gathered}
$$

Concordance correlation coefficients were 0.925 and 0.953 for Molly and Karoline, respectively. Proportions of mean squared prediction error (MSPE) attributable to mean and linear bias and random error were 10.6, 2.2 , and $87.2 \%$ for Molly model, and 1.3, 0.3, and $98.6 \%$ for Karoline model, respectively.

For dairy cow data $(\mathrm{n}=185)$, the root mean square error (RMSE) was 14.3 and $10.9 \%$ for Molly and Karoline models with proportions of MSPE related to mean, linear, and random error of 12, 8, and 80\% (Molly) and 1, 5, and 95\% (Karoline), respectively. Concordance correlation coefficients were 0.815 and 0.879 for Molly and Karoline, respectively.

With the mixed model analysis, the regression equations were

$$
\begin{gathered}
\text { Molly: } \mathrm{CH}_{4}(\mathrm{~g} / \mathrm{d})=0.84( \pm 0.313) \times \mathrm{pCH}_{4}(\mathrm{~g} / \mathrm{d}) \\
+62( \pm 10.5)(\mathrm{RMSPE}=33.1 \mathrm{~g} / \mathrm{d} \\
10.9 \% \text { of observed mean }) .
\end{gathered}
$$

Karoline: $\mathrm{CH}_{4}(\mathrm{~g} / \mathrm{d})=0.88( \pm 0.027) \times \mathrm{pCH}_{4}(\mathrm{~g} / \mathrm{d})$

$$
\begin{gathered}
+42( \pm 9.7)(\mathrm{RMSPE}=24.0 \mathrm{~g} / \mathrm{d} ; \\
7.9 \% \text { of observed mean }) .
\end{gathered}
$$

Residual analysis with the fixed regression model is shown in Figure 3. Both positive mean $(15 \mathrm{~g} / \mathrm{d} ; P<$ $0.001)$ and slope bias $(-0.057 ; P<0.01)$ were significant for the Molly model, but mean bias $(2 \mathrm{~g} / \mathrm{d})$ and slope bias $(-0.017)$ were not significant $(P>0.37)$ for the Karoline model. However, with mixed model regression the slope bias $(-0.138)$ was significant $(P<$ $0.001)$.

The following relationships between predicted OMD (pOMD) and observed OMD were formulated:

$$
\begin{gathered}
\text { Molly: OMD }(\mathrm{g} / \mathrm{kg})=0.39( \pm 0.064) \\
\times \mathrm{pOMD}(\mathrm{g} / \mathrm{kg})+460( \pm 45.0 .0) \\
(\mathrm{RMSPE}=51.9 ; 7.0 \% \text { of observed mean }) . \\
\text { Karoline: OMD }(\mathrm{g} / \mathrm{kg})=0.79( \pm 0.045) \\
\times \text { pOMD }(\mathrm{g} / \mathrm{d})+150( \pm 33.4)(\mathrm{RMSPE}=19.7 ; \\
2.7 \% \text { of observed mean }) .
\end{gathered}
$$

The RMSPE (51.6 vs. 19.7) was greater and CCC was smaller (0.32 vs. 0.90) for the Molly model compared 


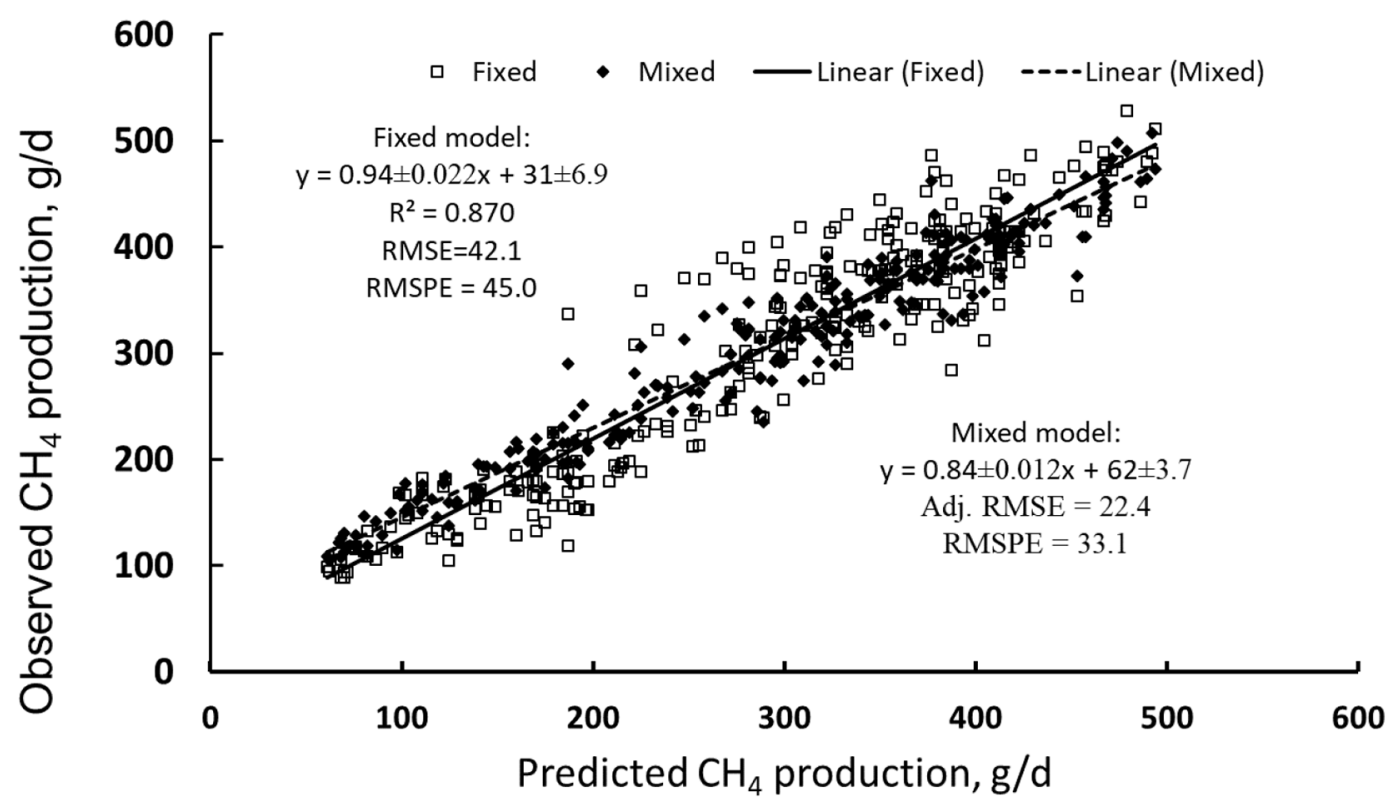

Figure 1. Relationship between predicted and observed $\mathrm{CH}_{4}$ production with fixed and mixed model regressions model regression analysis using the Molly model. RMSE = root mean square error; RMSPE = root mean square error of prediction; adj. = adjusted.

with the Karoline model. The proportions of MSPE related to mean, linear and random error were 50,28, and $22 \%$ (Molly) and 0, 24, and 76\% (Karoline), respectively.

\section{Effect of Input Variables on Residuals of $\mathrm{CH}_{4}$ Production}

With both models, the residuals of total $\mathrm{CH}_{4}$ yield were not related to DMI (Figure 4). However, underprediction of $\mathrm{CH}_{4}$ yield $(\mathrm{g} / \mathrm{kg}$ DMI $)$ decreased $(P<$ 0.001 ) with increased DMI for the Molly model but not for the Karoline model $(P=0.18)$. The effect of DMI on $\mathrm{CH}_{4}$ yield per $1 \mathrm{~kg}$ increase in DMI was stronger $[-0.28 \pm 0.034 ; P<0.001$ vs. $-0.09 \pm 0.041 ; P=0.03]$ for the Karoline model compared with the Molly model. Similarly, DMI was positively $(P<0.001)$ related to the efficiency of microbial $\mathrm{N}$ synthesis in the rumen for the Karoline model, but not for the Molly model $(P=$ 0.24 ). Quantitative responses were $0.15 \pm 0.016$ versus $-0.03 \pm 0.037 \mathrm{~g}$ of microbial $\mathrm{N} / \mathrm{kg}$ of digestible OM per $1 \mathrm{~g} / \mathrm{kg}$ increase in DMI/BW, respectively.

Observed OMD was positively $(P<0.001)$ related to the residuals of $\mathrm{CH}_{4}$ production of the Molly model [i.e., observed $\mathrm{CH}_{4}$ production increased more than predicted as diet digestibility increases (Figure 5)], whereas OMD was not related to the residuals of the Karoline model. The residuals of OMD were positively $(P<0.001)$ related to the residuals of $\mathrm{CH}_{4}$ production with both models. Residuals of total $\mathrm{CH}_{4}$ production were not related to the proportion of concentrates in either model $(P>0.39)$, but the Karoline model underpredicted $(P=0.01)$ the effect of concentrate proportion on $\mathrm{CH}_{4}$ yield.

Because of collinearity, the effects of dietary factors on the residuals of $\mathrm{CH}_{4}$ yield were analyzed by a multiple regression analysis (Table 3). The Molly model overpredicted the effects of dietary fat (ether extract; EE) concentration $(P=0.005$; i.e., the negative effect of increased EE concentration was greater than predicted). The effects of dietary NDF concentration and OMD were underpredicted $(P<0.001)$ by the Molly model. The Karoline model underpredicted the effects of dietary $\mathrm{CP}(P=0.09)$ and $\mathrm{EE}$ concentrations $(P=$ $0.02)$. The Molly model overpredicted $(P=0.002)$ the effect of feeding level expressed as DMI/BW on $\mathrm{CH}_{4}$, but there was no effect $(P=0.40)$ for the Karoline model.

Rumen fermentation pattern was analyzed for 110 diets in 26 studies (out of 55 studies) as reported. The models were accurate in predicting $\mathrm{CH}_{4}$ production as mmol per mol VFA $\left(\mathrm{CH}_{4} \mathrm{VFA}\right)$ observed 344; Molly 327; and Karoline 353 calculated according to Wolin (1960). The residuals of $\mathrm{CH}_{4}$ yield were significantly related $(P<0.001)$ to $\mathrm{CH}_{4}$ VFA (Figure 6). The residuals for the Molly model were also calculated from ruminal concentrations as $\mathrm{CH}_{4} \mathrm{VFA}$ and proportions of absorbed VFA were strongly correlated $\left(\mathrm{R}^{2}>0.99\right)$. 


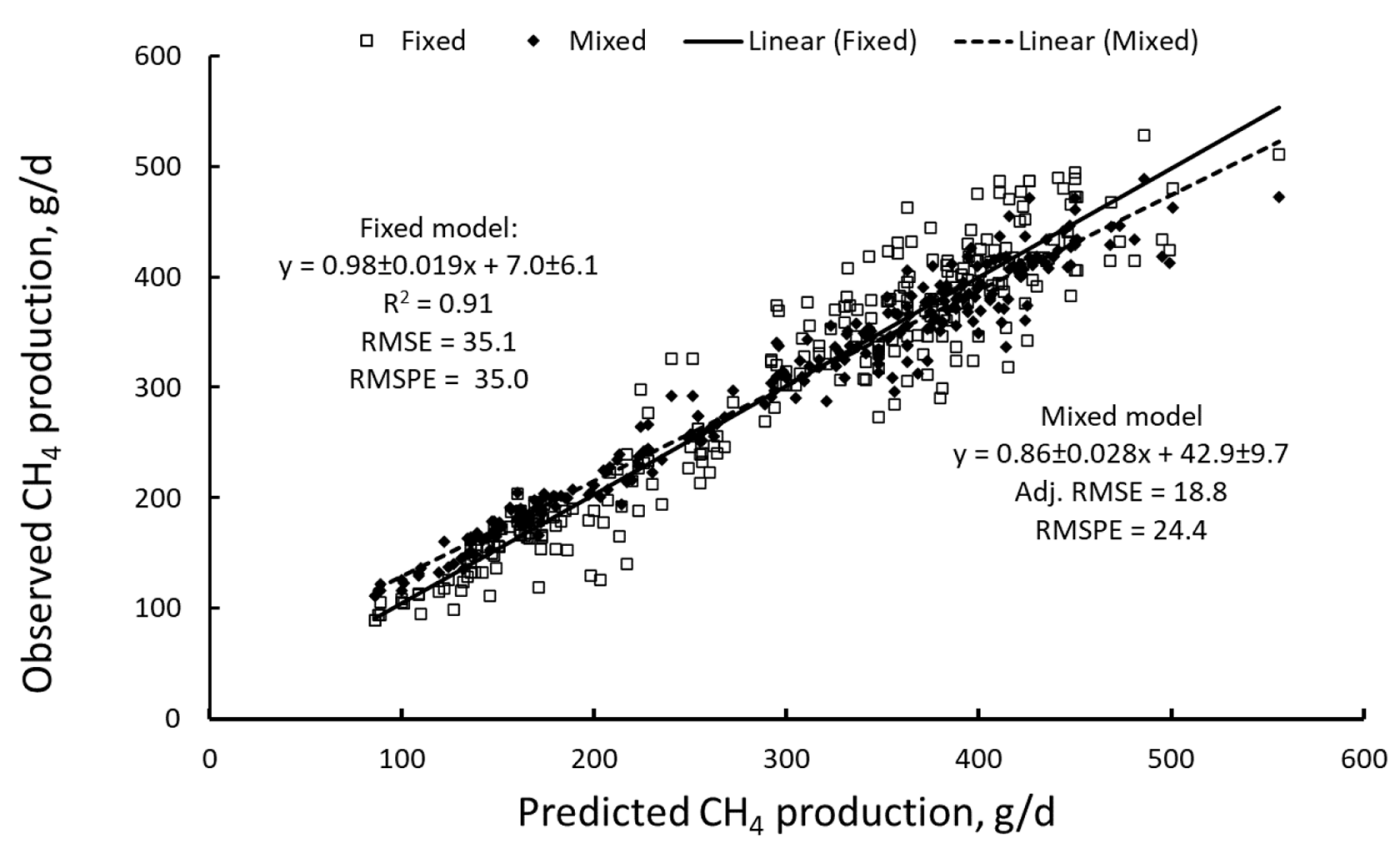

Figure 2. Relationship between predicted and observed $\mathrm{CH}_{4}$ production with fixed and mixed model regressions model regression analysis using the Karoline model. RMSE = root mean square error; RMSPE = root mean square error of prediction; adj. = adjusted.

\section{DISCUSSION}

In the current study, the performance of the Karoline and Molly models were evaluated in predicting $\mathrm{CH}_{4}$ production against observed $\mathrm{CH}_{4}$ production data from respiration chamber studies. The same intake and diet composition data were used for both models. Fixed and mixed model regression analyses were used to evaluate the performance of both models. A part of random study effects can be related to differences in calibration of respiration chambers. In the ring test by Gardiner et al. (2015), the recoveries of respiration chambers in the United Kingdom varied between 59 and $115 \%$. Such variation would increase MSPE in fixed model regression analysis. Ramin and Huhtanen (2015) reported significant laboratory effect on $\mathrm{CH}_{4}$ yield when the effect of other factors influencing $\mathrm{CH}_{4}$ production were considered. It is now recommended that recovery tests of chambers should be performed (Gerrits et al., 2018). In addition, differences in analytical methods used to determine parameter values between studies can contribute to between-study variation in model predictions.

\section{Model Performance}

As stated by Ramin and Huhtanen (2015), before any conclusions about differences in accuracy, precision, and usefulness of the models are made, all models should be evaluated using a common data set contain- ing wide ranges in those inputs, DMI and diet composition in this case. In the present study, RMSPE (11.6\%) of the Karoline model was slightly greater than the previous evaluation by Ramin and Huhtanen (2015). Intercepts ( 3 vs. 0$)$, slopes (1.02 vs. 0.92$), \mathrm{R}^{2}$ (0.92 vs. 0.91 ), and RMSPE (11.4 vs. $12.0 \%$ of observed mean) for the data $(\mathrm{n}=177)$ used in the previous evaluation (Ramin and Huhtanen, 2015) and for the additional data in the current data set $(\mathrm{n}=90)$. This suggests that model predictions are consistent irrespective of the data provided that number of observations is large enough and that the data cover wide ranges in DMI and diet composition. In the current study, the Molly and Karoline models were compared using a larger (267 treatment means) data set from respiration chamber studies compared with earlier studies (Benchaar et al., 1998; Mills et al., 2001). Because most of the model evaluations are based on a fixed model analysis, the following discussion about model performance will be based on the fixed model regression analysis. Compared with previous evaluations on the Molly model (Benchaar et al., 1998; Kebreab et al., 2008) the performance was better in terms of smaller RMSPE (14.9 vs. 36.9 and $36.1 \%$, respectively) and higher CCC (0.925 vs. 0.50$)$ compared with Kebreab et al. (2008). With the fixed regression model, $\mathrm{R}^{2}$ was greater than in Benchaar et al. (1998) study (0.87 vs. 0.70), probably partly reflecting the wider range of the data in the present study. In contrast to previous studies (Benchaar et al., 1998; Kebreab et al., 2008), mean and linear biases had small 
contributions to MSPE of the Molly model. In the current study, the Molly model underpredicted total $\mathrm{CH}_{4}$ production, whereas the reverse was true in the studies of Benchaar et al. (1998) and Kebreab et al. (2008).

\section{Comparison of Molly and Karoline Models}

Greater RMSPE for the Molly model compared with the Karoline model was mainly due to greater mean and linear biases and partly due to $35 \%$ greater random error. One reason for the greater RMSPE of the Molly model could be related to poorer predictions of digestibility compared with the Karoline model. One source of errors in predicting $\mathrm{CH}_{4}$ production by mechanistic models is inaccurate estimates of input variables (particularly NDF digestion kinetic parameters). For example, potential extent and rate of NDF digestion are seldom reported in respiration chamber studies. For the Karoline model, indigestible NDF and digestion rate of potentially digestible NDF were estimated from other reported data or tabulated values as described by Ramin and Huhtanen (2015). In the Molly model, rates of fiber and starch degradation are assumed to be partially intrinsic to the ingredient. Estimated extents of degradation are derived from in situ observations and used as a model input to calculate a reference rate for the model. However, such data are rarely reported for metabolism studies. Thus, they were estimated using in situ observations for similar ingredients reported in the literature. This will obviously introduce some variation and potentially some bias into the predictions. This approach can be removed by bias adjusting the inputs using observed mean ruminal outflows for each. Although such an approach helps ensure unbiased predictions, it hardly represents a truly independent evaluation of the model, and thus was not used herein. The relatively large underpredictions of ruminal digestion of NDF and starch suggest that the input rates were indeed an underprediction for the feeds used.

The Molly model predicted slightly smaller (287 vs. $300 \mathrm{~g} / \mathrm{d}) \mathrm{CH}_{4}$ production than the Karoline model. The difference was small considering that $18 \%$ less OM was apparently digested in the rumen and $17 \%$ less $\mathrm{CH}_{4}$ was produced per mole VFA with the Molly model compared with the Karoline model. In addition, in the Molly model, $\mathrm{CH}_{4}$ is not produced in the hindgut, whereas the Karoline model predicted that about 5 to $6 \%$ of $\mathrm{CH}_{4}$ production took place in the hindgut. Production of microbial OM was similar between the models, but the contribution of microbes as $\mathrm{H}_{2}$ sink is greater in the Karoline model compared with the Molly model. In the Karoline model an uptake of $8.1 \mathrm{~g}$ of $\mathrm{H}$ atoms per $\mathrm{kg}$ of cells (Czerkawski, 1986) is taken into account, whereas in the Molly model values range between 0.42 and 2.7 $\mathrm{g}$ of $\mathrm{H}$ atoms per $\mathrm{kg}$ of microbial growth. In the Molly model the contributions of biohydrogenation of fatty acids and rumen microbes as $\mathrm{H}_{2}$ sinks were only $6 \%$ of the total $\mathrm{H}_{2}$ production.

The difference between the models in ruminal digestion was due to the lower digestibility of NDF, and

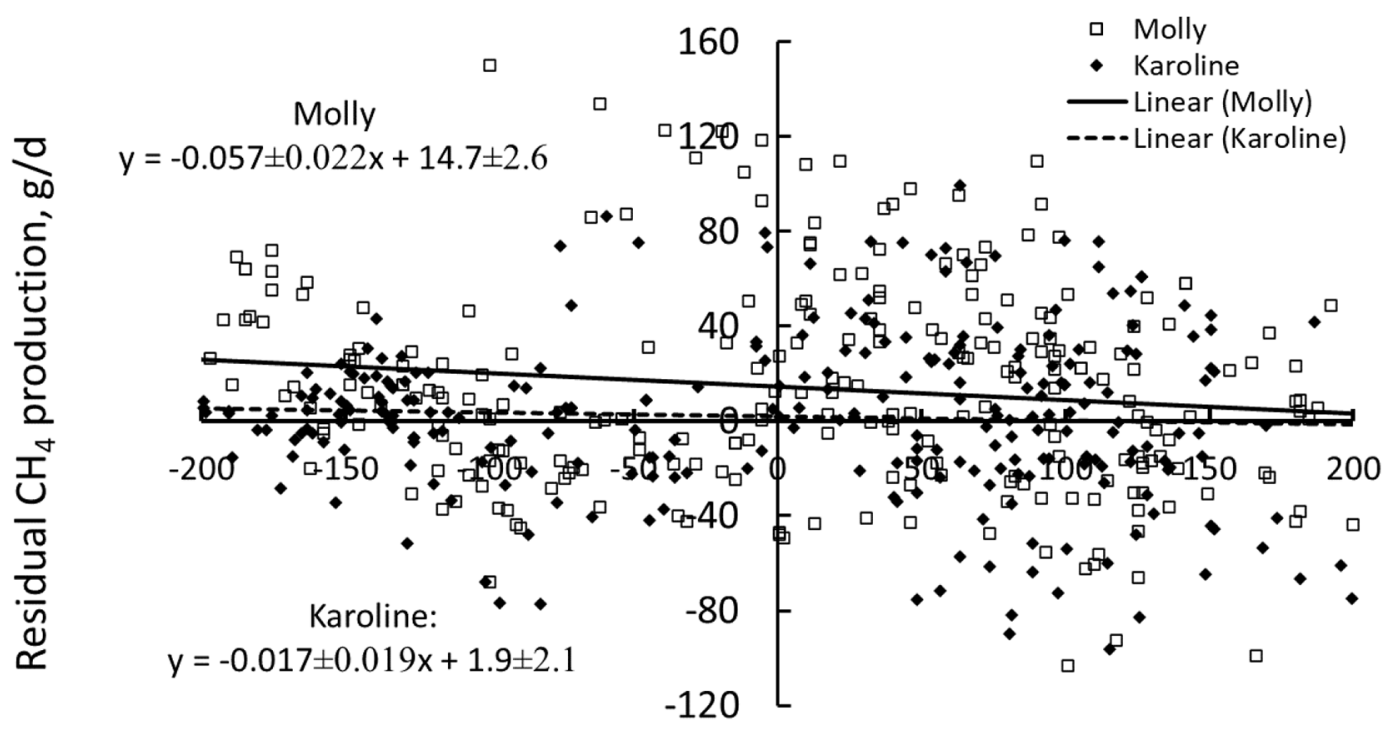

\section{Centered predicted $\mathrm{CH}_{4}$ production, $\mathrm{g} / \mathrm{d}$}

Figure 3. Relationship between predicted $\mathrm{CH}_{4}$ production and residuals of $\mathrm{CH}_{4}$ emissions (observed - predicted) using Molly and Karoline models. 

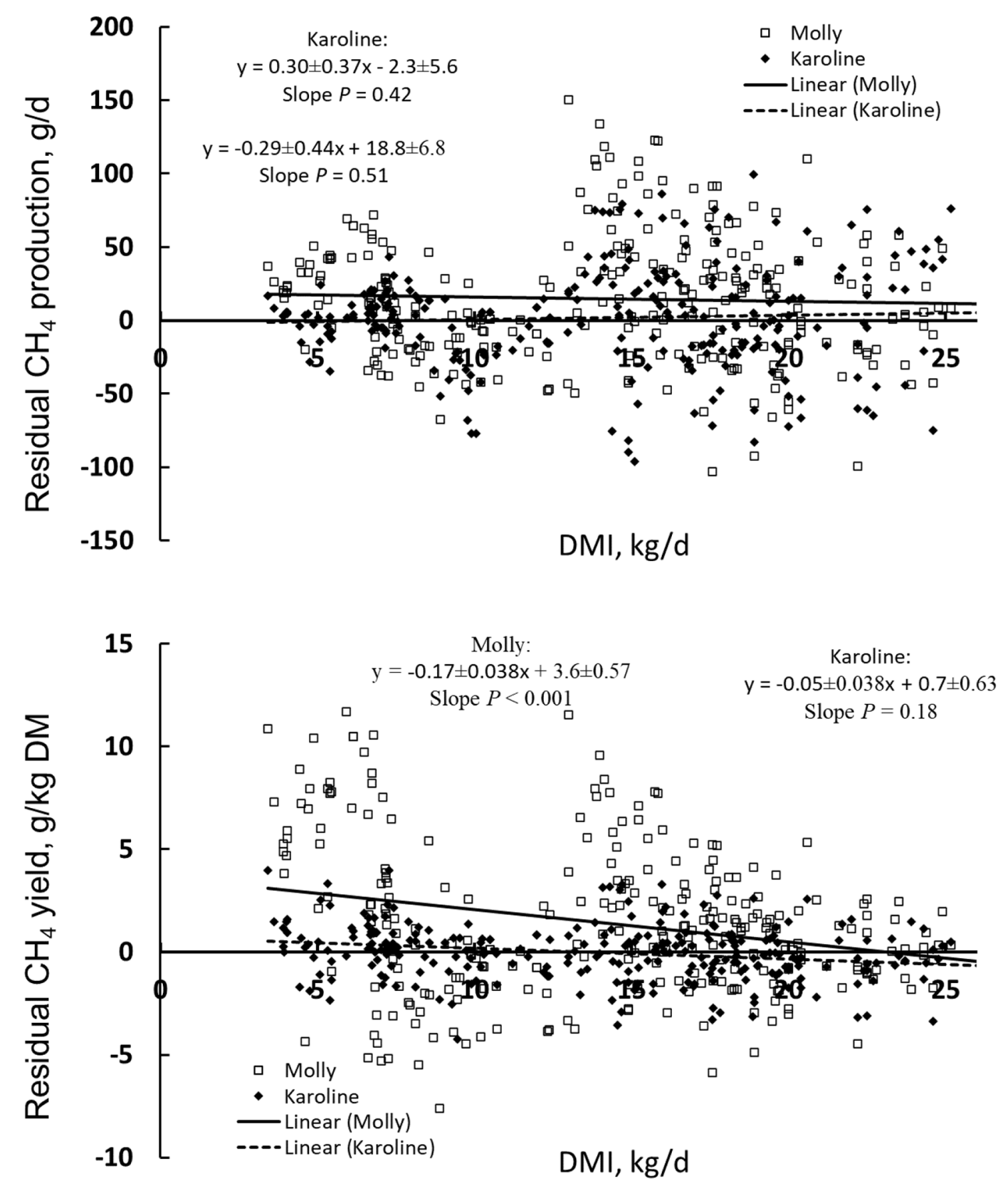

Figure 4. The effects of DMI on the residuals of the total $\mathrm{CH}_{4}$ production and $\mathrm{CH}_{4}$ yield predicted by Molly and Karoline models. For the Karoline model, the residuals of $\mathrm{CH}_{4}$ production and yield were not related $(P \geq 0.18)$ to DMI.

especially starch, with the Molly model compared with the Karoline model. Predicted ruminal starch digestibility was 0.60 and 0.80 for the Molly and Karoline models, respectively, for diets containing $>100 \mathrm{~g} / \mathrm{kg}$ DM starch ( $\mathrm{n}=184$ diets) The value predicted by the Karoline model agrees well with the review of Mills et al. (1999) for barley supplements, which was the main starch source in the current data. In contrast, the Molly model has been fitted primarily to diets based on maize grain and maize silage with much lower starch digestion.
The Karoline model predicted negligible fecal starch output, whereas the total starch digestibility according to the Molly predictions was 0.91 . Greater variability in fecal metabolic OM (OM - NDF) with the Molly model could be related to variable starch digestion. The predicted values agree well with $96 \mathrm{~g} / \mathrm{kg}$ DM reported by Nousiainen et al. (2009) in a meta-analysis of dairy cow digestibility studies.

The Molly model predicted greater duodenal NDF flow compared with the Karoline model (Table 2). Both 
models underpredicted ruminal NDF digestibility, but the Karoline model was more accurate (observed 0.58, Karoline 0.542, and Molly 0.484). Inaccuracies in NDF digestion can result from inaccurate digestion kinetic parameters that are seldom reported in respiration chamber studies. However, there are also differences between the models in the structure of NDF digestion model. For example, the Molly model assumes only lignin as an indigestible fraction of cell walls, whereas in the Karoline model pdNDF is defined as a difference between total NDF and indigestible NDF that is determined by $12 \mathrm{~d}$ in situ incubation in small pore size in situ bags (Huhtanen et al., 1994). In the Karoline model digestion of pdNDF follows the first-order kinetics, as do the cellulose and hemicellulose pools in the Molly model.
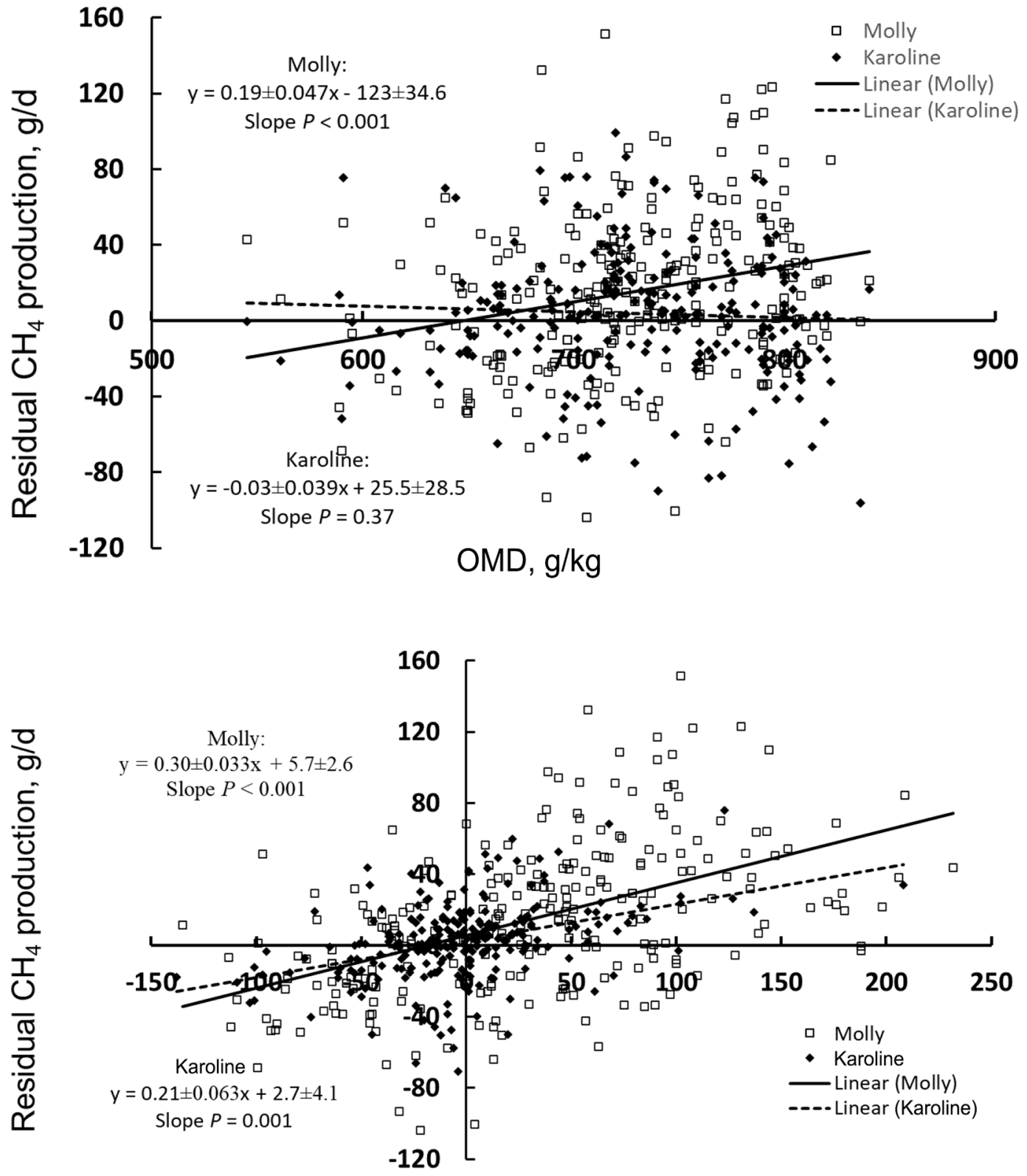

Residual of OMD, $\mathrm{g} / \mathrm{kg}$

Figure 5. Relationship between observed OM digestibility (OMD; above) and residuals of OMD to residuals of $\mathrm{CH}_{4}$ production (below). 


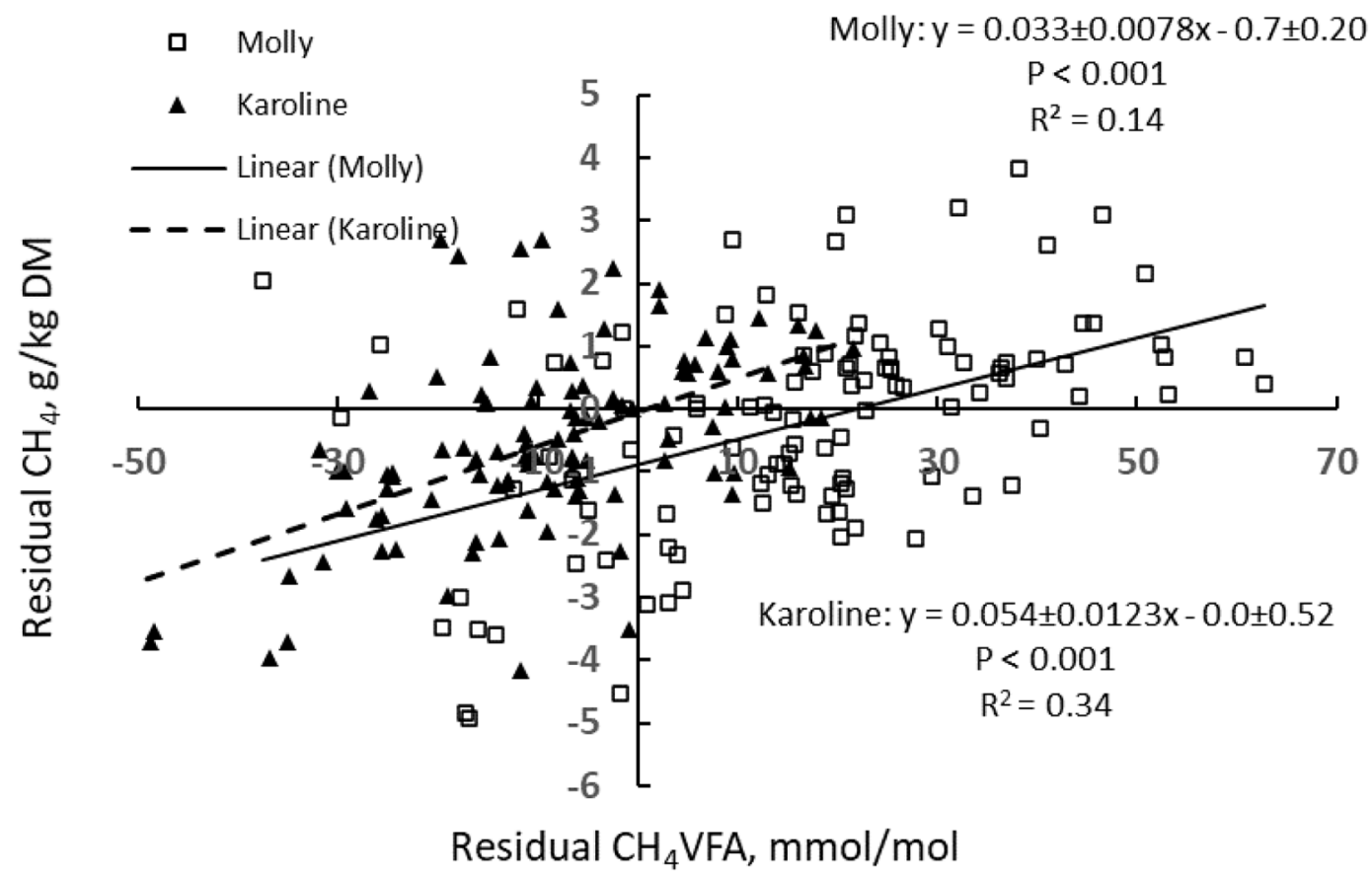

Figure 6. The effects of $\mathrm{CH}_{4} \mathrm{VFA}$ calculated rumen fermentation stoichiometry according to Wolin (1960) on the residuals of $\mathrm{CH}_{4}$ yield. The values of $\mathrm{CH}_{4} \mathrm{VFA}$ were centered to mean $=0$.

\section{Residual Analysis}

Feed Intake. Residual analysis was conducted to evaluate if the model structure systematically influenced the residuals. The level of DMI did not influence the residuals for $\mathrm{CH}_{4}$ production or $\mathrm{CH}_{4}$ yield, but the Molly model underpredicted $\mathrm{CH}_{4}$ yield at low compared with high DMI. Reduced $\mathrm{CH}_{4}$ yield with increased DMI level can be attributed to the depression in diet digestibility with increased intake. However, the reduction in $\mathrm{CH}_{4}$ cannot completely be accounted for by reduced digestibility. For example, Yan et al. (2000) reported a decrease of $7.8 \mathrm{~kJ} / \mathrm{MJ}$ (about $9 \%$ ) in the proportion of $\mathrm{CH}_{4}$ energy of gross energy per multiple of maintenance. Greater depression in $\mathrm{CH}_{4}$ yield with increased intake is likely to be related to improved efficiency of microbial synthesis. A faster ruminal passage rate with increased intake lowers the retention time of microbes in the rumen and, as a result, increases microbial cell yield per unit of energy fermented by diluting maintenance expenditure (Russell et al., 1992). With increased efficiency more fermented carbon is used for microbial growth and less to gas and VFA production, such that the importance of microbial growth as a hydrogen sink in the rumen increases. Linear bias in $\mathrm{CH}_{4}$ yield with the Molly model is likely to be related to minimal effects of feeding level on diet digestibility and the efficiency of microbial synthesis. In the Karoline model fluid and particle passage rate increase with increased feeding that decreases diet digestibility and increases

Table 3. Multiple regression analysis of dietary factors (per $10 \mathrm{~g} / \mathrm{kg}$ of DM unless otherwise stated) and intake level influencing the residuals of the predictions of $\mathrm{CH}_{4}$ yield $\left(\mathrm{CH}_{4} / \mathrm{DMI}, \mathrm{g} / \mathrm{kg}\right)$

\begin{tabular}{lccccccc}
\hline & \multicolumn{3}{c}{ Molly } & & \multicolumn{3}{c}{ Karoline } \\
\cline { 2 - 3 } \cline { 7 - 8 } Item $^{1}$ & Estimate & $\mathrm{SE}$ & \multirow{2}{*}{ P-value } & & Estimate & \multirow{2}{*}{$\mathrm{SE}$} & $P$-value \\
\hline Intercept & -12.9 & 3.21 & $<0.001$ & & -1.2 & 2.31 & 0.62 \\
$\mathrm{DMI} / \mathrm{BW}, \mathrm{g} / \mathrm{kg}$ & -0.106 & 0.0329 & 0.002 & & -0.021 & 0.0236 & 0.40 \\
$\mathrm{CP}$ & -0.111 & 0.0556 & 0.05 & & 0.069 & 0.0400 & 0.09 \\
$\mathrm{NDF}$ & 0.115 & 0.0303 & $<0.001$ & & 0.013 & 0.0221 & 0.55 \\
$\mathrm{EE}$ & -0.326 & 0.121 & 0.007 & & 0.210 & 0.0865 & 0.02 \\
OMD & 0.217 & 0.0371 & $<0.001$ & & -0.005 & 0.0267 & 0.85 \\
RMSE & 3.23 & & & & 2.32 & & \\
\hline
\end{tabular}

${ }^{1} \mathrm{EE}=$ ether extract; OMD = organic matter digestibility; RMSE $=$ root mean square error. 
the efficiency of microbial synthesis. The passage kinetic parameters of particle fraction were derived from a meta-analysis of rumen evacuation data (Krizsan et a., 2012) and dividing rumen retention time of iNDF between nonescapable and escapable compartments in ratios of 40:60 and 20:80 for forages and concentrates, respectively.

In the Molly model, liquid passage is by mass balance with greater feed intake, leading to more water entering the rumen by osmotic pull. This increases the liquid passage rate, which carries small and medium particles with it (Gregorini et al., 2015). Thus, increased DMI will result in greater flow and a depression in digestion; however, the results herein suggest that this mechanism is not adequate to explain the observed results of OMD.

Digestibility. The residuals for total $\mathrm{CH}_{4}$ production were positively related to observed diet OMD with the Molly model, indicating that the effects of digestibility were underestimated. This could be related to overprediction of OMD of low digestibility diets compared with high digestibility diets. Residuals of $\mathrm{CH}_{4}$ yield were positively related to the residuals of OMD with both models with the relationship being stronger with the Molly model. Given the mechanistic nature of both models, it is hardly surprising that underpredictions of OMD resulted in underpredictions of $\mathrm{CH}_{4}$ yield, underscoring the importance of accurate predictions of diet digestibility. With the Karoline model, most of RMSPE of OMD prediction was due to random error, suggesting the prediction errors of OMD were not systematically related to the model structure, but more likely due to biased estimates of some key input variables such as concentration of iNDF and digestion rate of pdNDF. In sensitivity analysis (Huhtanen et al., 2015), these were the key variables determining OMD. In their analysis, differences of $10 \mathrm{~g} / \mathrm{kg}$ DMI in forage iNDF concentration and $0.01 / \mathrm{h}$ in digestion rate of pdNDF caused differences of 1.0 and $2.4 \%$ in predicted $\mathrm{CH}_{4}$ production. In the Molly model both mean and linear biases contributed a large proportion of RMSPE of OMD, which also indicates systematic errors increased RMSPE of $\mathrm{CH}_{4}$ yield. The principles of ruminal digestion in the Molly and Karoline models are similar, but the execution of those concepts differ. In the Karoline model, ruminal digestion of dietary components is based on firs-order kinetics of nutrient digestion and a 2-compartment rumen passage model (Danfær et al., 2006; Huhtanen et al., 2015). Intrinsic ruminal NDF digestion rate is regulated by the ratio of NFC/NDF. The Molly model is also based on first-order kinetics with a 3 pools of particle passage model. The base rates of degradation of fiber, starch, and protein are defined by in situ estimates, and modified in the model according to ruminal $\mathrm{pH}$ and microbe pool size. Passage of small and medium particles are defined as a fraction of the liquid passage rates with the medium passage being a much smaller fraction (Gregorini et al., 2015).

Fat. Dietary fat concentration was not associated with reduced $\mathrm{CH}_{4}$ yield in the Molly predictions, whereas observed $\mathrm{CH}_{4}$ yield decreased, resulting in a negative residual (Table 3). This is surprising because biohydrogenation of fatty acid is a $\mathrm{H}_{2}$ sink in the Molly model and fatty acids are not fermented. It suggests that the stoichiometric coefficients driving VFA production in that model are not appropriate, or that the empirical scheme for predicting ruminal VFA production is inadequate. The effects of fat supplementation on $\mathrm{CH}_{4}$ yield have been variable in the literature. Moate et al. (2011) reported a decrease of $0.078 \mathrm{~g} / \mathrm{kg}$ DMI in $\mathrm{CH}_{4}$ yield per $1 \mathrm{~g} / \mathrm{kg}$ DM increase in fat concentrations, which is close to the value $(0.077)$ predicted by the Karoline model. Patra (2013) reported a corresponding decrease of 0.066 in his meta-analysis, whereas in the study of Eugène et al. (2008) the effect of fat was nonsignificant. In the analysis of the international individual cow database (Niu et al., 2018), increased dietary EE concentration decreased $\mathrm{CH}_{4}$ yield by $0.045 \mathrm{~g} / \mathrm{kg}$ DMI per $1 \mathrm{~g} / \mathrm{kg}$ DM. The effects of fat supplementation on $\mathrm{CH}_{4}$ yield were highly variable between individual studies (Beauchemin et al., 2008; Moate et al., 2011) and even between different meta-analysis, which can be related to the type of fatty acids (Patra, 2013). Fatty acids C12:0 and C18:3 were especially effective in reducing $\mathrm{CH}_{4}$ production. In contrast, Grainger and Beauchemin (2011) did not find any differences between fatty acids on $\mathrm{CH}_{4}$ production.

The responses to fat supplementation also can depend on the type of basal forage in the diet. Linseed oil supplementation decreased $\mathrm{CH}_{4}$ yield more (4.0 vs. 1.7 $\mathrm{g} / \mathrm{kg} \mathrm{DM}$ ) with a corn silage-based diet compared with red clover silage-based diet (Benchaar et al., 2015). Similar interactions were observed in molar proportions of propionate in rumen VFA. Rumen fermentation patterns in cows fed a grass silage-based diet seem to be rather resistant to changes when dietary fat inclusion is increased (Shingfield et al., 2008). In addition, Brask et al. (2013) showed that forage species and harvest time are related to $\mathrm{CH}_{4}$ production, but forage characteristics do not interact with EE to reduce $\mathrm{CH}_{4}$.

Protein. The Karoline model predicted a decrease in $\mathrm{CH}_{4}$ yield with increased dietary $\mathrm{CP}$ concentration, but because no relationship between $\mathrm{CP}$ and $\mathrm{CH}_{4}$ was found in observed data, the residual was positively related to dietary $\mathrm{CP}$ concentration. The reverse was true for the Molly model. In single studies increased dietary $\mathrm{CP}$ concentration did not influence $\mathrm{CH}_{4}$ production in dairy cows fed diets based on different forages (Gidlund et al., 2015; Hynes et al., 2016; Niu et al., 2018). In 
contrast, fermentation equations developed by Bannink et al. (2006) and Sveinbjörnsson et al. (2006) predict approximately 30 to $50 \%$ less $\mathrm{CH}_{4}$ from protein fermentation compared with the fermentation of carbohydrates. Therefore, adjusting the fermentation equation of protein (Sveinbjörnsson et al., 2006) could improve the predictions of $\mathrm{CH}_{4}$ yield by the Karoline model.

Rumen Fermentation. Both models were relatively accurate in predicting $\mathrm{CH}_{4}$ production per unit of VFA in studies in which rumen fermentation parameters were determined. However, the predictions were imprecise. Imprecision can partly be related to different schedules in rumen fluid sampling. The positive relationship between the residuals of stoichiometric $\mathrm{CH}_{4}\left(\mathrm{CH}_{4} \mathrm{VFA}\right)$ and the residuals of $\mathrm{CH}_{4}$ yield in Karoline predictions indicate potential to improve model predictions of $\mathrm{CH}_{4}$ production by improving fermentation models. The fermentation model in Karoline was developed by assuming that absorption rates between individual VFAs are similar (i.e., the production rates of individual VFA are same as their molar proportions). In the Molly model, absorption rates are regulated by $\mathrm{pH}$ and therefore ruminal concentration ratios do not represent production ratios. The substrate-based VFA stoichiometry models could be improved by considering the $\mathrm{pH}$ effects of the rumen VFA pattern (Bannink et al., 2006). In the Molly model absorption rate of propionate is faster than other VFA as indicated by lower $\mathrm{CH}_{4} \mathrm{VFA}$ in absorbed VFA than in ruminal concentrations. However, the results of Sutton et al. (2003) based on using 3 labeled VFA indicated that that molar proportions of net production and ruminal concentrations were strongly $\left(\mathrm{R}^{2}>\right.$ $0.90)$ correlated with slope close to 1.0 for acetate and propionate, but the proportion of produced butyrate was less than the proportional concentration at lower concentration. In the Molly predictions the amount of starch digested postruminally was positively related to $\mathrm{CH}_{4} \mathrm{VFA}$ (i.e., increased starch flow from the rumen decreased propionate production). One problem of substrate-based fermentation models is that the fermentation pattern of the same dietary component can depend on the composition of the basal diet. Increasing dietary starch concentration usually increases propionate, but in animals fed grass-silage diets increased starch intake usually increases butyrate instead of propionate (Sveinbjörnsson et al., 2006; Huhtanen et al., 2013). Similarly, the effects of fat supplementation on rumen fermentation pattern can be related to the basal forage in the diet (Benchaar et al., 2015).

\section{CONCLUSIONS}

In the current study, we evaluated the performance of both the Karoline and Molly models to predict $\mathrm{CH}_{4}$ production. When analyzed with the mixed model regression analysis, there was good agreement between predicted and observed values for $\mathrm{CH}_{4}$ production for both models, suggesting that the models could accurately predict the differences in these variables within a study. Prediction errors of $\mathrm{CH}_{4}$ production were smaller with the Karoline model compared with the Molly model. We emphasize the necessity and importance of accurate input estimates, especially for digestion kinetic parameters. In the studies with VFA analysis the residuals of stoichiometric $\mathrm{CH}_{4}$ yield per mole of VFA were positively related to the residuals of $\mathrm{CH}_{4}$ yield with both models, suggesting that there is potential for improving predictions of $\mathrm{CH}_{4}$ from improving fermentation models. It is concluded that the Karoline and Molly models could be a useful tool in understanding the model behavior, predicting $\mathrm{CH}_{4}$ production from ruminants, and developing mitigation strategies.

\section{ACKNOWLEDGMENTS}

The fellowship of postdoctoral research of Marko Kass at the Swedish University of Agricultural Sciences in 2015-2016 was supported by the Swedish Institute (Visby Programme, Stockholm, Sweden). The authors have not stated any conflicts of interest.

\section{REFERENCES}

Allen, M. S., and D. R. Mertens. 1988. Evaluation constraints of fiber digestion by rumen microbes. J. Nutr. 118:261-270. https://doi .org/10.1093/jn/118.2.261.

Axelsson, J. 1949. The amount of produced methane energy in the European metabolic experiments with adult cattle. Annals Royal Agric. Col. (Sweden) 16:404-418.

Baldwin, R. L. 1995. Modeling Ruminant Digestion and Metabolism. Chapman and Hall.

Baldwin, R. L., J. H. M. Thornley, and D. E. Beever. 1987. Metabolism of the lactating cow II. Digestive elements of a mechanistic model. J. Dairy Res. 54:107-131. https://doi.org/10.1017/ S0022029900025231.

Bannink, A., J. Kogut, J. Dijkstra, J. France, E. Kebreab, A. M. van Vuuren, and S. Tamminga. 2006. Estimation of the stoichiometry of volatile fatty acid production in the rumen of lactating cows. J. Theor. Biol. 238:36-51. https://doi.org/10.1016/j.jtbi.2005.05.026.

Beauchemin, K. A., M. Kreuzer, F. O'Mara, and T. A. McAllister. 2008. Nutritional management for enteric methane abatement: A review. Aust. J. Exp. Agric. 48:21-27. https://doi.org/10.1071/ EA07199.

Benchaar, C., F. Hassanat, R. Martineau, and R. Gervais. 2015. Linseed oil supplementation to dairy cows fed diets based on red clover silage or corn silage: Effects on methane production, rumen fermentation, nutrient digestibility, $\mathrm{N}$ balance, and milk production. J. Dairy Sci. 98:7993-8008. https://doi.org/10.3168/jds.2015 -9398 .

Benchaar, C., J. Rivest, C. Pomar, and J. Chiquette. 1998. Prediction of methane production from dairy cows using existing mechanistic models and regression equations. J. Anim. Sci. 76:617-627. https: //doi.org/10.2527/1998.762617x.

Bibby, J., and H. Toutenburg. 1977. Prediction and Improved Estimation in Linear Models. John Wiley and Sons. 
Blaxter, K. L., and J. L. Clapperton. 1965. Prediction of the amount of methane produced by ruminants. Br. J. Nutr. 19:511-522. https: //doi.org/10.1079/BJN19650046.

Boston, R., and M. Hanigan. 2000. Segmented, constrained, nonlinear, multi-objective, dynamic optimization methodology applied to the dairy cow ration formulation problem in a situation where some of the constraints may be discontinuous. Pages 257-274 in Nutrient Digestion and Utilization in Farm Animals: Modelling Approaches. E. Kebreab, J. Dijkstra, A. Bannink, W. J. J. Gerrits, and J. France, ed. CAB International.

Brask, M., P. Lund, A. L. F. Hellwing, M. Poulsen, and M. R. Weisbjerg. 2013. Enteric methane production, digestibility and rumen fermentation in dairy cows fed different forages with and without rapeseed fat supplementation. Anim. Feed Sci. Technol. 184:67-79. https://doi.org/10.1016/j.anifeedsci.2013.06.006.

Czerkawski, J. W. 1986. An Introduction to Rumen Studies. Robert Maxwell.

Danfær, A., P. Huhtanen, P. Udén, J. Sveinbjörnsson, and V. Volden. 2006. The Nordic dairy cow model, Karoline-description. Pages 383-406 in Nutrient Digestion and Utilization in Farm Animals Modelling Approaches. E. Kebreab, J. Dijkstra, A. Bannink, W. J. J. Gerrits, and J. France, ed. CABI Publishing.

Eugène, M., D. Massé, J. Chiquette, and C. Benchaar. 2008. Metaanalysis on the effects of lipid supplementation on methane production in lactating dairy cows. Can. J. Anim. Sci. 88:331-337. https://doi.org/10.4141/CJAS07112.

Gardiner, T. D., M. D. Coleman, F. Innocenti, J. Tompkins, A. Connor, P. C. Garnsworthy, J. M. Moorby, C. K. Reynolds, A. Waterhouse, and D. Wills. 2015. Determination of the absolute accuracy of UK chamber facilities used in measuring methane emissions from livestock. Measurement 66:272-279. https://doi.org/10.1016/ j.measurement.2015.02.029.

Gerrits, W. J. J., E. Labussière, C. K. Reynolds, C. C. Metges, B. Kuhla, P. Lund, M. R. Weisbjerg, and J. Dijkstra. 2018. Letter to the Editor: Recovery test results as a prerequisite for publication of gaseous exchange measurements. J. Dairy Sci. 101:4703-4704. https://doi.org/10.3168/jds.2017-13705

Gidlund, H., M. Hetta, S. J. Krizsan, S. Lemosquet, and P. Huhtanen. 2015. Effects of soybean meal or canola meal on milk production and methane emissions in lactating dairy cows fed grass silagebased diets. J. Dairy Sci. 98:8093-8106. https://doi.org/10.3168/ jds.2015-9757.

Grainger, C., and K. A. Beauchemin. 2011. Can enteric methane emissions from ruminants be lowered without lowering their production? Anim. Feed Sci. Technol. 166-167:308-320. https://doi.org/ 10.1016/j.anifeedsci.2011.04.021.

Gregorini, P., P. Beukes, G. Waghorn, D. Pacheco, and M. Hanigan. 2015. Development of an improved representation of rumen digesta outflow in a mechanistic and dynamic model of a dairy cow. Ecol. Modell. 313:293-306. https://doi.org/10.1016/j.ecolmodel.2015.06 .042 .

Hanigan, M. D., J. A. D. R. N. Appuhamy, and P. Gregorini. 2013. Revised digestive parameter estimates for the Molly cow model. J. Dairy Sci. 96:3867-3885. https://doi.org/10.3168/jds.2012-6183.

Hanigan, M. D., C. C. Palliser, and P. Gregorini. 2009. Altering the representation of hormones and adding consideration of gestational metabolism in a metabolic cow model reduced prediction errors. J. Dairy Sci. 92:5043-5056. https://doi.org/10.3168/jds.2008-1922.

Hanigan, M. D., C. C. Palliser, and A. G. Rius. 2008. Modelling lactation potential in an animal model. Pages 485-506 in Mathematical Modelling in Animal Nutrition. J. France and E. Kebreab, ed. CAB International.

Hanigan, M. D., A. G. Rius, E. S. Kolver, and C. C. Palliser. 2007. A redefinition of the representation of mammary cells and enzyme activities in a lactating dairy cow model. J. Dairy Sci. 90:38163830. https://doi.org/10.3168/jds.2007-0028.

Hristov, A. N., E. Kebreab, M. Niu, J. Oh, A. Bannink, A. R. Bayat, T. M. Boland, A. F. Brito, D. P. Casper, L. A. Crompton, J. Dijkstra, M. Eugène, P. C. Garnsworthy, N. Haque, A. L. F. Hellwing, P. Huhtanen, M. Kreuzer, B. Kuhla, P. Lund, J. Madsen, C. Mar- tin, P. J. Moate, S. Muetzel, C. Muñoz, N. Peiren, J. M. Powell, C. K. Reynolds, A. Schwarm, K. J. Shingfield, T. M. Storlien, M. R. Weisbjerg, D. R. Yáñez-Ruiz, and Z. Yu. 2018. Symposium review: Uncertainties in enteric methane inventories, measurement techniques, and prediction models. J. Dairy Sci. 101:6655-6674. https://doi.org/10.3168/jds.2017-13536.

Huhtanen, P. 2015. Karoline in Excel. Pages 12-17 in Proceedings of the 6th Nordic Feed Science Conference, Uppsala, Sweden. P. Udén, ed. Swedish University of Agricultural Sciences.

Huhtanen, P., S. Jaakkola, and J. Nousiainen. 2013. An overview of silage research in Finland: from ensiling innovation to advances in dairy cow feeding. Agric. Food Sci. 22:35-56. https://doi.org/10 $.23986 /$ afsci.6632.

Huhtanen, P., K. Kaustell, and S. Jaakkola. 1994. The use of internal markers to predict total digestibility and duodenal flow of nutrients in cattle given six different diets. Anim. Feed Sci. Technol. 48:211-227. https://doi.org/10.1016/0377-8401(94)90173-2.

Huhtanen, P., M. Ramin, and P. Udén. 2015. Nordic dairy cow model Karoline in predicting methane emissions: 1 . Model description and sensitivity analysis. Livest. Sci. 178:71-80. https://doi.org/10 .1016/j.livsci.2015.05.009.

Hynes, D. N., S. Stergiadis, A. Gordon, and T. Yan. 2016. Effects of concentrate crude protein content on nutrient digestibility, energy utilization, and methane emissions in lactating dairy cows fed fresh-cut perennial grass. J. Dairy Sci. 99:8858-8866. https://doi .org/10.3168/jds.2016-11509.

IPCC (International Panel on Climate Change). 2006. Revised IPCC guidelines for national greenhouse gas inventories. Chapter 10 , Vol. 4: Agriculture, Forestry and Other Land Use. Accessed Feb. 17, 2012. https://www.ipcc-nggip.iges.or.jp/support/Primer 2006GLs.pdf.

Jentsch, W., M. Schweigel, F. Weissbach, H. Scholze, W. Pitroff, and M. Derno. 2007. Methane production in cattle calculated by the nutrient composition of the diet. Arch. Anim. Nutr. 61:10-19. https://doi.org/10.1080/17450390601106580.

Johnson, K. A., and D. E. Johnson. 1995. Methane emissions from cattle. J. Anim. Sci. 73:2483-2492. https://doi.org/10.2527/1995 $.7382483 \mathrm{x}$.

Kass, M. 2022. Supplemental File. Mendeley Data, V1. https://doi. org $/ 10.17632 / 83 \mathrm{cg} 3 j \mathrm{bmsh} .1$.

Kebreab, E., K. A. Johnson, S. L. Archibeque, D. Pape, and T. Wirth. 2008. Model for estimating enteric methane emissions from United States dairy and feedlot cattle. J. Anim. Sci. 86:2738-2748. https: //doi.org/10.2527/jas.2008-0960.

Krizsan, S. J., L. Nyholm, J. Nousiainen, K.-H. Südekum, and P. Huhtanen. 2012. Comparison of in vitro and in situ methods in evaluation of forage in vivo organic matter digestibility in ruminants. J. Anim. Sci. 90:3162-3173. https://doi.org/10.2527/jas .2011-4347.

Lin, L. I.-K. 1989. A concordance correlation coefficient to evaluate reproducibility. Biometrics 45:255-268. https://doi.org/10.2307/ 2532051

Littell, R. C., G. A. Milliken, W. W. Stroup, and R. D. Wolfinger. 1996. SAS System for Mixed Models. SAS Institute Inc.

Mills, J. A., J. Dijkstra, A. Bannink, S. B. Cammell, E. Kebreab, and J. France. 2001. A mechanistic model of whole-tract digestion and methanogenesis in the lactating dairy cow: model development, evaluation, and application. J. Anim. Sci. 79:1584-1597. https:// doi.org/10.2527/2001.7961584x.

Mills, J. A. N., J. France, and J. Dijkstra. 1999. A review of starch digestion in the lactating dairy cow and proposals for a mechanistic model. 1. Dietary starch characterization and ruminal starch digestion. J. Anim. Feed Sci. 8:291-340. https://doi.org/10.22358/ jafs $/ 68938 / 1999$.

Moate, P. J., S. R. O. Williams, C. Grainger, M. C. Hannah, E. N. Ponnampalam, and R. J. Eckard. 2011. Influence of cold-pressed canola, brewers grain and hominy meal as dietary supplements suitable for reducing enteric methane emissions from lactating dairy cows. Anim. Feed Sci. Technol. 166-167:254-264. https:// doi.org/10.1016/j.anifeedsci.2011.04.069. 
Moe, P. W., and H. F. Tyrrell. 1979. Methane production in dairy cows. J. Dairy Sci. 62:1583-1586. https://doi.org/10.3168/jds .S0022-0302(79)83465-7.

Niu, M., J. A. D. R. N. Appuhamy, A. B. Leytem, R. S. Dungan, and E. Kebreab. 2016. Effect of dietary crude protein and forage contents on enteric methane emissions and nitrogen excretion from dairy cows simultaneously. Anim. Prod. Sci. 56:312-321. https:// doi.org/10.1071/AN15498.

Niu, M., E. Kebreab, A. N. Hristov, J. Oh, C. Arndt, A. Bannink, A. R. Bayat, A. F. Brito, T. Boland, D. Casper, L. A. Crompton, J. Dijkstra, M. A. Eugène, P. C. Garnsworthy, M. N. Haque, A. L. F. Hellwing, P. Huhtanen, M. Kreuzer, B. Kuhla, P. Lund, J. Madsen, C. Martin, S. C. McClelland, M. McGee, P. J. Moate, S. Muetzel, C. Muñoz, P. O'Kiely, N. Peiren, C. K. Reynolds, A. Schwarm, K. J. Shingfield, T. M. Storlien, M. R. Weisbjerg, D. R. Yáñez-Ruiz, and Z. Yu. 2018. Prediction of enteric methane production, yield, and intensity in dairy cattle using an intercontinental database. Glob. Change Biol. 24:3368-3389. https://doi .org/10.1111/gcb.14094.

Nousiainen, J., M. Rinne, and P. Huhtanen. 2009. A meta-analysis of feed digestion in dairy cows. 1. The effects of forage and concentrate factors on total diet digestibility. J. Dairy Sci. 92:5019-5030. https://doi.org/10.3168/jds.2008-1833.

NRC. 2001. Nutrient Requirements of Dairy Cattle. 7th Revised Edition, Subcommittee on Dairy Cattle Nutrition, Committee on Animal Nutrition, Board on Agriculture and Natural Resources, National Research Council, National Academy Press.

Patra, A. K. 2013. The effect of dietary fats on methane emissions, and its other effects on digestibility, rumen fermentation and lactation performance in cattle: A meta-analysis. Livest. Sci. 155:244-254. https://doi.org/10.1016/j.livsci.2013.05.023.

Ramin, M., and P. Huhtanen. 2015. Nordic dairy cow model Karoline in predicting methane emissions: 2. Model evaluation. Livest. Sci. 178:81-93. https://doi.org/10.1016/j.livsci.2015.05.008.

Russell, J. B., J. D. O'Connor, D. G. Fox, P. J. Van Soest, and C. J. Sniffen. 1992. A net carbohydrate and protein system for evaluating cattle diets: I. Ruminal fermentation. J. Anim. Sci. 70:35513561. https://doi.org/10.2527/1992.70113551x

Shingfield, K. J., S. Ahvenjärvi, V. Toivonen, A. Vanhatalo, P. Huhtanen, and M. J. Griinari. 2008. Effect of incremental lev- els of sunflower oil in the diet on ruminal lipid metabolism in lactating cows. Br. J. Nutr. 99:971-983. https://doi.org/10.1017/ S0007114507853323.

St-Pierre, N. R. 2003. Reassessment of biases in predicted nitrogen flows to the duodenum by NRC 2001. J. Dairy Sci. 86:344-350. https://doi.org/10.3168/jds.S0022-0302(03)73612-1.

Sutton, J. D., M. S. Dhanoa, S. V. Morant, J. France, D. J. Napper, and E. Schuller. 2003. Rates of production of acetate, propionate and butyrate in the rumen of lactating dairy cows given normal and low roughage diets. J. Dairy Sci. 86:3620-3633. https://doi .org/10.3168/jds.S0022-0302(03)73968-X.

Sveinbjörnsson, J., P. Huhtanen, and P. Udén. 2006. The Nordic dairy cow model, Karoline - Development of volatile fatty acid sub-model. Pages 1-14 in Nutrient Digestion and Utilization in Farm Animals: Modeling Approaches. E. Kebreab, J. Dijkstra, A. Bannink, W. J. J. Gerrits, and J. France, ed. CABI.

Tylutki, T. P., D. G. Fox, V. M. Durbal, L. O. Tedeschi, J. B. Russell, M. E. VanAmburgh, T. R. Overton, L. E. Chase, and A. N. Pell. 2008. Cornell Net Carbohydrate and Protein System: A model for precision feeding of dairy cattle. Anim. Feed Sci. Technol. 143:174202. https://doi.org/10.1016/j.anifeedsci.2007.05.010.

Wolin, M. J. 1960. A theoretical rumen fermentation balance. J. Dairy Sci. 43:1452-1459. https://doi.org/10.3168/jds.S0022 -0302(60)90348-9.

Yan, T., R. E. Agnew, F. J. Gordon, and M. G. Porter. 2000. Prediction of methane energy output in dairy and beef cattle offered grass silage-based diets. Livest. Prod. Sci. 64:253-263. https://doi .org/10.1016/S0301-6226(99)00145-1.

\section{ORCIDS}

M. Kass ๑ https://orcid.org/0000-0001-5333-2461

M. Ramin (- https://orcid.org/0000-0002-0028-896X

M. D. Hanigan () https://orcid.org/0000-0002-5639-9677

P. Huhtanen ๑ https://orcid.org/0000-0001-7855-7448 